\title{
SOCIAL AND PROFESSIONAL EVALUATION OF PARA AND TETRAPLEGICS
}

\author{
By Jerzy Kiwerski, M.D. and Teresa Chrostowska, M.D. \\ Institute of Rehabilitation and Reconstructive Surgery at Konstancin, Warsaw School of \\ Medicine, Nr. Warsaw, Poland
}

\begin{abstract}
An analysis of the social conditions of I9I patients with paraplegia or tetraplegia is made. Patients being mainly in villages may have difficult social conditions. On the whole, good functional results were achieved with 35 per cent of patients obtaining work, and 52 per cent had functional walking ability.
\end{abstract}

Key words: Spinal cord injury; Social evaluations and vocational reintegration.

THE treatment of patients with spinal cord injury (SCI) following trauma is a difficult and long-lasting problem. Although treatment is more effective as is shown by improvement in both mortality and in overall function there must be great concern regarding the increasing number of patients with severe disability who are now being discharged from hospital and who will have considerable difficulty in coping with the activities of daily living under often difficult home conditions.

This report is based on data obtained from case histories, interviews and questionnaires sent to 300 patients previously treated in the acute stage in our Institute 5-I5 years previously and who at that time were I8-60 years of age. Questionnaires were sent to Ioo patients each with cervical, thoracic and lumbar spine injuries, with neurological defects, but patients who were known to have died at home were disregarded from these studies. In spite of this, 24 further deaths were reported, 64 patients did not reply and 2I patients were not traced.

\section{Clinical material}

One hundred and ninety one patients responded ( 58 with injuries to the cervical spine, 84 thoracic and 49 of lumbar). The majority of respondents ( 55 per cent) had only an elementary education, 25 per cent had primary or secondary technical education, with 20 per cent having had a secondary or University education.

Table I presents time of observation of the analysed group in relation to the degree of nervous system injury, giving an average time from injury of $9 \cdot 3$ years. Only a small group of patients have been observed longer than I 3 years, which reflects the relatively small numbers dealt with by the Unit in its initial years when mortality was also greater and since this group were more difficult to trace. The high incidence of complete neurological injury follows from the admission procedure of our hospital and from the repeated admissions of this group who remain more dependent on the hospital.

The greatest importance is given to the teaching of self-care since the independence of disabled patients depends on the degree of self-care achieved. 


\section{TABLE I}

Duration of observation, and severity of the neurological lesion

\begin{tabular}{|c|c|c|c|c|c|c|}
\hline \multirow{2}{*}{\multicolumn{2}{|c|}{$\begin{array}{l}\text { Degree of } \\
\text { nervous system } \\
\text { trauma }\end{array}$}} & \multicolumn{4}{|c|}{ Time of observation, in years } & \multirow[t]{2}{*}{ Total } \\
\hline & & $5-7$ & $8-10$ & I I $-\mathrm{I} 4$ & Above 14 & \\
\hline \multirow{3}{*}{$\begin{array}{l}\text { complete } \\
\text { incomplete }\end{array}$} & I & $\begin{array}{r}4 \mathrm{I} \\
8\end{array}$ & $\begin{array}{r}34 \\
3\end{array}$ & $\begin{array}{r}27 \\
6\end{array}$ & $\begin{array}{l}4 \\
2\end{array}$ & $\begin{array}{r}106 \\
19\end{array}$ \\
\hline & $\begin{array}{l}1 \\
2\end{array}$ & 13 & $\begin{array}{r}3 \\
14\end{array}$ & I I & 2 & 40 \\
\hline & 3 & 4 & I3 & 9 & 一 & 26 \\
\hline \multicolumn{2}{|l|}{ Total } & 66 & 64 & 53 & 8 & I9I \\
\hline
\end{tabular}

The level of achievement related to the nature of nervous system injury is presented in Table II.

Complete self-care (dressing, washing, transfers, eating and hygienic procedures) was acquired by the majority of patients ( 56 per cent). Such efficiency can be reached only by patients with lesser neurological disturbances but it should be emphasised that half of the disabled patients with limited ability to achieve selfcare constitute an important group (35 per cent) requiring, in certain activities, the help of a second person. The patients recorded as being insignificantly independent or not fully self-reliant, are essentially persons with tetraplegia or old people afflicted with other illnesses and with persisting paralysis of the lower extremities.

\section{TABLE II}

Degree of independence related to the severity of neurological disability

\begin{tabular}{lccccc}
\hline $\begin{array}{c}\text { Severity of the } \\
\text { nervous system } \\
\text { trauma }\end{array}$ & Full & Limited & Insignificant & Dependent & Total \\
\cline { 2 - 5 } $\begin{array}{c}\text { Tetraplegia } \\
\begin{array}{l}\text { Paresis of upper } \\
\text { and lower } \\
\text { extremities }\end{array}\end{array}$ & 2 & 7 & 6 & 7 & 22 \\
$\begin{array}{l}\text { Paralysis of lower } \\
\text { extremities }\end{array}$ & I6 & 20 & - & - & 36 \\
$\begin{array}{l}\text { Paresis of lower } \\
\text { extremities }\end{array}$ & 46 & 36 & 4 & 2 & 84 \\
Total & I06 & 66 & - & - & 49 \\
\hline
\end{tabular}

\section{Locomotion capability}

Under home conditions, the use of a wheelchair is a convenient form of locomotion. However, when the handicapped individual tries to participate in the life of the community, he finds many barriers which discourage him to leave his home. During hospital treatment we try to train the patient in ambulation being at the same time aware that only a small group of patients will use walking as a principal form of locomotion. 
Wheelchair users constitute the larger group (45 per cent) but the fact that 52 per cent of patients may walk in a useful manner deserves attention. From among the patients with paresis, 5I (62 per cent) walk without orthopaedic equipment. Only seven patients stayed in bed mainly because of general or systemic disease, other complications or pain (Table III).

\section{TABLE III}

Principal form of locomotion related to the neurological status

\begin{tabular}{|c|c|c|c|c|c|}
\hline \multirow[b]{2}{*}{$\begin{array}{l}\text { Neurological } \\
\text { status }\end{array}$} & \multicolumn{4}{|c|}{ Principal form of locomotion } & \multirow[b]{2}{*}{$\begin{array}{l}\text { Confined } \\
\text { to bed }\end{array}$} \\
\hline & $\begin{array}{l}\text { Without } \\
\text { orthopaedic } \\
\text { equipment }\end{array}$ & $\begin{array}{l}\text { With a } \\
\text { stick }\end{array}$ & $\begin{array}{l}\text { With } \\
\text { crutches }\end{array}$ & Wheelchair & \\
\hline $\begin{array}{l}\text { Tetraplegia } \\
\text { Paresis of lower } \\
\text { and upper }\end{array}$ & - & - & I & 20 & I \\
\hline $\begin{array}{l}\text { extremities } \\
\text { Paralysis of lower }\end{array}$ & 26 & 6 & 4 & - & I \\
\hline $\begin{array}{l}\text { extremities } \\
\text { Paresis of lower }\end{array}$ & - & - & I5 & 63 & 6 \\
\hline extremities & 25 & 12 & IO & 2 & - \\
\hline
\end{tabular}

\section{Complications}

Complications were reported by more than half of the patients, the commonest being of pain of different intensification, character and location ( 36 per cent) (Table IV). These pains were of the nature of root pains appearing under the influence of various factors, atmospheric, infection or even psychic. Pain occurred more frequently in cervical spine injury than in injuries elsewhere. Bed sores developed in 17 per cent of patients and were particularly frequent in paraplegics or tetraplegics staying for a long time in a wheelchair. Excluding

\section{TABLE IV}

The main complications seen, related to the neurological status

\begin{tabular}{|c|c|c|c|c|c|}
\hline \multirow{2}{*}{$\begin{array}{c}\text { Neurological } \\
\text { status }\end{array}$} & \multicolumn{4}{|c|}{ Complications } & \multirow[t]{2}{*}{ Tota } \\
\hline & Pain & Bedsores & Urinary & Others & \\
\hline Tetraplegia & I 8 & II & 8 & 6 & 43 \\
\hline $\begin{array}{l}\text { Paresis of lower } \\
\text { and upper }\end{array}$ & & & & & \\
\hline extremities & 19 & 2 & 2 & I2 & 35 \\
\hline Paralysis of lower & & & & & \\
\hline $\begin{array}{c}\text { extremities } \\
\text { Paresis of lower }\end{array}$ & I9 & I7 & 7 & 7 & 50 \\
\hline $\begin{array}{l}\text { Paresis of lower } \\
\text { extremities }\end{array}$ & I3 & 2 & I & IO & 26 \\
\hline Total & 69 & 32 & I 8 & 35 & I 54 \\
\hline
\end{tabular}


transitory infection, urinary complications were relatively infrequent but included urolithiasis as well as infection associated with systemic illness. Other complications included neurological periarthritic ossifications, disturbance of alimentary canal activity, haemorrhoids and pulmonary complications.

\section{Professional activity}

The most numerous group are pensioners ( 50 per cent) but many patients (35 per cent) earn their living either in their former profession, or in a new one, or in a cooperative for the disabled. Young people, up to 40 years of age, constitute the greatest working group (43 per cent), 20 patients ( 10 per cent) were maintained by the family and nine patients were in the process of being retrained for a new vocation (Table $\mathrm{V}$ ).

\section{TABLE V}

Vocational activity in relation to the patient's age

\begin{tabular}{|c|c|c|c|c|c|c|}
\hline \multirow{2}{*}{$\begin{array}{c}\text { Actual } \\
\text { age }\end{array}$} & \multicolumn{6}{|c|}{ Vocational activity } \\
\hline & $\begin{array}{l}\text { Former } \\
\text { vocation }\end{array}$ & $\begin{array}{c}\text { Other } \\
\text { vocation }\end{array}$ & $\begin{array}{l}\text { Cooperative } \\
\text { for the } \\
\text { disabled }\end{array}$ & Training & Pension & $\begin{array}{l}\text { Maintained by } \\
\text { the family }\end{array}$ \\
\hline $\mathrm{Up}$ to 40 & 15 & 8 & $2 \mathrm{I}$ & 9 & 42 & 8 \\
\hline $4 \mathrm{I}-60$ & 6 & 3 & IO & - & 46 & I I \\
\hline above 60 & 2 & I & - & - & 8 & I \\
\hline Total & 23 & 12 & $3 I$ & 9 & 96 & 20 \\
\hline
\end{tabular}

\section{Discussion}

This report is limited to the difficulties most frequently encountered by patients with paresis or paralysis. Self-care, locomotion and health complications are among those factors creating the greatest difficulties in rehabilitation, but we consider professional activity to be an important measure of the value of comprehensive rehabilitation.

This analysis suggests that results from treatment should be more positively evaluated. Our early observation that paraplegics use a wheelchair as a principal form of locomotion, to the disadvantage of elbow crutches, is confirmed. In this group of patients the principal emphasis should be given to self-care activities rather than to locomotion. Attention is called to the significant number of complications occurring in this group. Although pain is common, it does not in general cause so many problems being of low intensity and of periodical occurrence. Disabled persons often cannot obtain employment in which to use their acquired qualifications and hardly 35 per cent are gainfully employed with the most numerous group being pensioners.

\section{Conclusions}

I. In the analysed group of chronically ill persons, difficulties in self-care, in locomotion, and in obtaining employment, create the greatest problems. 
2. Disabled persons with paralysis of the lower extremities prefer a wheelchair as their principal form of locomotion.

3. In rehabilitation of persons with lower extremity paralysis, great emphasis should be laid on training in self-care activities in the wheelchair even at the cost of decreasing training in ambulation because only a small group of patients will continue to use this form of locomotion.

4. The aim should be to increase the opportunity of employment of disabled individuals who even after changing their vocation cannot get work.

\section{SUMMARY}

The most important problems of chronically ill individuals after spinal cord trauma have been assessed from data obtained from case histories, social interviews and questionnaires obtained from I9I patients. The average time from trauma to observation was 9.3 years. Complete self-care was achieved by 56 per cent, a degree of ambulation by 52 per cent and 35 per cent had a useful vocational activity.

The authors advise the positive evaluation of results of treatment after trauma, and call attention to the necessity of giving greater emphasis on training in activities of daily living even at the expense of decreasing training in ambulation, since only a small group of patients use ambulation as a form of locomotion. The difficulties in obtaining employment by disabled persons even after changing their vocation is stressed.

\section{RÉSUMÉ}

D'après l'analyse les dossiers et les enquétes sociaux nous avons discuter les differentes problémes des malades chroniques après lesions traumatiques de moelle épiniére. Sur 300 enquétes envoyées, nous avons reçu I9I reponses. Le temps moyenne d'observation après l'accident est 9,3 ans.

Nous avons analysée les possibilitès de 'self-service', de la locomotion, de l'activité professionelle et complications par rapport au niveau et degré de lesion de la moelle épinière. Sur les résultats de cette analyse les auteurs sont apprécier positivement le traitement prècoce des traumatismes du rachis. Dans le programe de la rééducation le plus importante semble etre 'daily living training'. L'apprentissage de la marche chez les paraplegiques est moins importante, car la plupart des paraplegiques n'accepte pas cette façon de la locomotion. Nous signalons les difficultes pour trouver la past de travail pour les invalides paraplegiques, même après la réadaptation professionelle.

\section{ZUSAMMENFASSUNG}

Auf dem Grund Langjährigen Erfahrung, die wichtigsten Problemen der Inwalidität nach Rückenmarklaesion, vorgestellt wurde. Auf 300 ausgeschickten Fragebogen, I9I Inwaliden geantwortet haben. Danach die ausgefüllten Fragebogen analysiert wurden.

Die Analyse betrift haupstens

I. Selbstbedienungfächigkeit

2. Lokomotion möglichkeit

3. Berufliche aktivität

4. Komplikationen.

Die Autoren kritisch betrachten den Inwalidängutt und zur volgenden Schlussvolgerung gekommen sind. Das wichtigste in Rehabilitationbehandlung gute vorbereitung zur Selbstbedienung ist.

Der Querschnitsgelähmte sehr selten die Gehmöglichkeiten zy Hause nutzt. Praktisch in alltag benutzt den Roll-stuhl. Deswegen ist zwecklos zu intensiv die Gehübungen in Rehabilitationprozess durchführen.

Ausser dem ist auf ewidente Schwierigkeiten in Berufsumschullung und Berufsaktiviesirung gezeigt. 


\section{REFERENCES}

Bellamy, R., Pitts, F. W. \& Stauffer, E. S. (1973). Respiratory complications in traumatic quadriplegia. F. Neurosurg., 39, 596-600.

Bosch, A., STAUfFer, E. S. \& Nickel, V. L. (I97I). Incomplete traumatic quadriplegia. F $A M A, 216,473-478$.

Chrostowska, T., KiwERski, J. \& MichalowsKa, B. (I972). Results of treatment of the lesions in lower part of the spine. Chir. Narz. Ruchu i Ortop. Pol., 37, 645-649.

Chrostowska, T., Kiwerski, J. \& Makowski, J. (1978). Results of treatment of dorsal spine injuries. Chir. Narz. Ruchu i Ortop. Pol., 43, 105-108.

Frankel, H. L., Hancock, D. O. \& MelzaK, J. (1969). The value of postural reduction in the initial management of closed injuries of the spine. Paraplegia, 7, I79-192.

Guttmann, L. (1973). Spinal Cord Injuries. Comprehensive Management and Research. Blackwell, Oxford.

HubBard, D. D. (1976). Fractures of the dorsal and lumbar spine. Orthop. Clin. North Am., 7, 605-614.

KIWERSKI, J. (I980). An analysis of results of conservative and surgical treatment in patients with cervical spine lesion. Chir. Narz. Ruchu i Ortop. Pol., 45, 309-313.

Kiwerski, J., Fibiger, E., Chrostowska, T. \& Krasuski, M. (1980). Late results of treatment of the lesions lumbar spine. Polski Tyg. Lekarski, 47, I813-1815.

Kraus, J. F. \& Franti, Ch. E., Borhani No. (1979). Survival with an acute spinal cord injury. F. Chron. Dis., 32, 269-83.

Kurtzke, J. F. (1975). Epidemiology of spinal cord injury. Exp. Neurol., 48, I63-236.

Weiss, M., BuczyŃski, A. Z. \& Kiwerski, J. (I979). Surgical treatment of unstable fractures of the spine. XXII Scientific Meeting PTO i Tr., PZWL-Warszawa, 209-2I2. 